\title{
World Map of the Köppen-Geiger climate classification updated
}

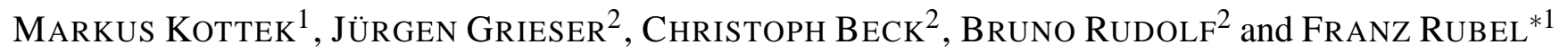 \\ ${ }^{1}$ Biometeorology Group, University of Veterinary Medicine Vienna, Vienna, Austria \\ ${ }^{2}$ Global Precipitation Climatology Centre, Deutscher Wetterdienst, Offenbach, Germany
}

(Manuscript received December 19, 2005; in revised form February 28, 2006; accepted April 10, 2006)

\begin{abstract}
The most frequently used climate classification map is that of Wladimir Köppen, presented in its latest version 1961 by Rudolf Geiger. A huge number of climate studies and subsequent publications adopted this or a former release of the Köppen-Geiger map. While the climate classification concept has been widely applied to a broad range of topics in climate and climate change research as well as in physical geography, hydrology, agriculture, biology and educational aspects, a well-documented update of the world climate classification map is still missing. Based on recent data sets from the Climatic Research Unit (CRU) of the University of East Anglia and the Global Precipitation Climatology Centre (GPCC) at the German Weather Service, we present here a new digital Köppen-Geiger world map on climate classification, valid for the second half of the $20^{\text {th }}$ century.
\end{abstract}

\section{Zusammenfassung}

Die am häufigsten verwendete Klimaklassifikationskarte ist jene von Wladimir Köppen, die in der letzten Auflage von Rudolf Geiger aus dem Jahr 1961 vorliegt. Seither bildeten viele Klimabücher und Fachartikel diese oder eine frühere Ausgabe der Köppen-Geiger Karte ab. Obwohl das Schema der Klimaklassifikation in vielen Forschungsgebieten wie Klima und Klimaänderung aber auch physikalische Geographie, Hydrologie, Landwirtschaftsforschung, Biologie und Ausbildung zum Einsatz kommt, fehlt bis heute eine gut dokumentierte Aktualisierung der Köppen-Geiger Klimakarte. Basierend auf neuesten Datensätzen des Climatic Research Unit (CRU) der Universität von East Anglia und des Weltzentrums für Niederschlagsklimatologie (WZN) am Deutschen Wetterdienst präsentieren wir hier eine neue digitale Köppen-Geiger Weltkarte für die zweite Hälfte des 20. Jahrhunderts.

\section{Introduction}

The first quantitative classification of world climates was presented by the German scientist Wladimir Köppen (1846-1940) in 1900; it has been available as world map updated 1954 and 1961 by Rudolf Geiger (1894-1981). Many of the early German publications (KÖPPEN, 1900; GEIGER 1954, 1957) from this area are not easily accessible today; here we refer to the comprehensive summaries on this topic given by, e.g., HANTEL (1989) or ESSENWANGER (2001).

Köppen was trained as a plant physiologist and realised that plants are indicators for many climatic elements. His effective classification was constructed on the basis of five vegetation groups determined by the French botanist De Candolle referring to the climate zones of the ancient Greeks (SANDERSON, 1999) The five vegetation groups of Köppen distinguish between plants of the equatorial zone (A), the arid zone (B), the warm temperate zone (C), the snow zone (D) and the polar zone (E). A second letter in the classification consid-

\footnotetext{
${ }^{*}$ Corresponding author: Franz Rubel, Biometeorology Group, Department of Natural Sciences, University of Veterinary Medicine Vienna, 1210 Vienna, Austria, e-mail: franz.rubel@vu-wien.ac.at
}

ers the precipitation (e.g. Df for snow and fully humid), a third letter the air temperature (e.g. Dfc for snow, fully humid with cool summer).

Although various authors published enhanced Köppen classifications or developed new classifications, the climate classification originally developed by Köppen (here referred to as Köppen-Geiger classification) is still the most frequently used climate classification. Many textbooks on climatology reproduce a world map of Köppen-Geiger climate classes, due to the lack of recent maps mostly a copy of one of the historical hand-drawn maps (e.g., KRAUS, 2004). In order to close this gap we present a digital world map of the Köppen-Geiger climate classification calculated from up-to-date global temperature and precipitation data sets.

The importance of an updated digital map may be recognized by looking at global and regional studies that use the Köppen-Geiger climate classification. Representative for hydrological studies PEEL et al. (2001) identified and explained the continental-scale variability in annual runoff by applying Köppen's climate classification. Applications to climate modelling have been presented, for example, by LoHMANN et al. (1993) to validate general circulation model control runs of present 
Table 1: Key to calculate the climate formula of Köppen and Geiger for the main climates and subsequent precipitation conditions, the first two letters of the classification. Note that for the polar climates (E) no precipitation differentiations are given, only temperature conditions are defined. This key implies that the polar climates (E) have to be determined first, followed by the arid climates (B) and subsequent differentiations into the equatorial climates (A) and the warm temperate and snow climates (C) and (D), respectively. The criteria are explained in the text.

\begin{tabular}{|c|c|c|}
\hline Type & Description & Criterion \\
\hline $\begin{array}{l}\text { A } \\
\text { Af } \\
\text { Am } \\
\text { As } \\
\text { Aw }\end{array}$ & $\begin{array}{l}\text { Equatorial climates } \\
\text { Equatorial rainforest, fully humid } \\
\text { Equatorial monsoon } \\
\text { Equatorial savannah with dry summer } \\
\text { Equatorial savannah with dry winter }\end{array}$ & $\begin{array}{l}\mathrm{T}_{\min } \geq+18^{\circ} \mathrm{C} \\
\mathrm{P}_{\min } \geq 60 \mathrm{~mm} \\
\mathrm{P}_{\text {ann }} \geq 25\left(100-\mathrm{P}_{\min }\right) \\
\mathrm{P}_{\min }<60 \mathrm{~mm} \text { in summer } \\
\mathrm{P}_{\min }<60 \mathrm{~mm} \text { in winter }\end{array}$ \\
\hline $\begin{array}{l}\text { B } \\
\text { BS } \\
\text { BW }\end{array}$ & $\begin{array}{l}\text { Arid climates } \\
\text { Steppe climate } \\
\text { Desert climate }\end{array}$ & $\begin{array}{l}\mathrm{P}_{\text {ann }}<10 \mathrm{P}_{\text {th }} \\
\mathrm{P}_{\text {ann }}>5 \mathrm{P}_{\text {th }} \\
\mathrm{P}_{\text {ann }} \leq 5 \mathrm{P}_{\text {th }}\end{array}$ \\
\hline $\begin{array}{l}\mathrm{C} \\
\mathrm{Cs} \\
\mathrm{Cw} \\
\mathrm{Cf}\end{array}$ & $\begin{array}{l}\text { Warm temperate climates } \\
\text { Warm temperate climate with dry summer } \\
\text { Warm temperate climate with dry winter } \\
\text { Warm temperate climate, fully humid }\end{array}$ & $\begin{array}{l}-3{ }^{\circ} \mathrm{C}<\mathrm{T}_{\min }<+18{ }^{\circ} \mathrm{C} \\
\mathrm{P}_{\mathrm{smin}}<\mathrm{P}_{\mathrm{wmin}}, \mathrm{P}_{\mathrm{wmax}}>3 \mathrm{P}_{\mathrm{smin}} \text { and } \mathrm{P}_{\mathrm{smin}}<40 \mathrm{~mm} \\
\mathrm{P}_{\mathrm{wmin}}<\mathrm{P}_{\text {smin }} \text { and } \mathrm{P}_{\mathrm{smax}}>10 \mathrm{P}_{\mathrm{wmin}} \\
\text { neither } \mathrm{Cs} \text { nor } \mathrm{CW}\end{array}$ \\
\hline $\begin{array}{l}\text { D } \\
\text { Ds } \\
\text { Dw } \\
\text { Df }\end{array}$ & $\begin{array}{l}\text { Snow climates } \\
\text { Snow climate with dry summer } \\
\text { Snow climate with dry winter } \\
\text { Snow climate, fully humid }\end{array}$ & $\begin{array}{l}\mathrm{T}_{\min } \leq-3{ }^{\circ} \mathrm{C} \\
\mathrm{P}_{\text {smin }}<\mathrm{P}_{\text {wmin }}, \mathrm{P}_{\mathrm{wmax}}>3 \mathrm{P}_{\text {smin }} \text { and } \mathrm{P}_{\text {smin }}<40 \mathrm{~mm} \\
\mathrm{P}_{\text {wmin }}<\mathrm{P}_{\text {smin }} \text { and } \mathrm{P}_{\text {smax }}>10 \mathrm{P}_{\mathrm{wmin}} \\
\text { neither Ds nor Dw }\end{array}$ \\
\hline $\begin{array}{l}\mathbf{E} \\
\text { ET } \\
\text { EF }\end{array}$ & $\begin{array}{l}\text { Polar climates } \\
\text { Tundra climate } \\
\text { Frost climate }\end{array}$ & $\begin{array}{l}\mathrm{T}_{\max }<+10{ }^{\circ} \mathrm{C} \\
0{ }^{\circ} \mathrm{C} \leq \mathrm{T}_{\max }<+10{ }^{\circ} \mathrm{C} \\
\mathrm{T}_{\max }<0{ }^{\circ} \mathrm{C}\end{array}$ \\
\hline
\end{tabular}

climate as well as greenhouse gas warming simulations. KLEIDON et al. (2000) investigated the maximum possible influence of vegetation on the global climate by conducting climate model simulations. Both, LOHMANN et al. (1993) and KLEIDON et al. (2000) applied the Köppen classification to model simulations to illustrate the differences in simulation results. The updated KöppenGeiger climates presented here will support future studies similar to those discussed above.

\section{Data and method}

Two global data sets of climate observations have been selected to update the historical world map of the Köppen-Geiger climate classes. Both are available on a regular 0.5 degree latitude/longitude grid with monthly resolution. The first data set is provided by the Climatic Research Unit (CRU) of the University of East Anglia (MitChelL and Jones, 2005) and delivers grids of monthly climate observations from meteorological stations comprising nine climate variables from which only temperature is used in this study. The temperature fields have been analysed from time-series observations, which are checked for inhomogeneities in the stationrecords by an automated method. This data set covers the global land areas excluding Antarctica. It is publicly available (www.cru.uea.ac.uk) and will be referred to as CRU TS 2.1.

The second data set (BECK et al., 2005) is provided by the Global Precipitation Climatology Centre (GPCC) located at the German Weather Service. This new gridded monthly precipitation data set covers the global land areas excluding Greenland and Antarctica. It was developed on the basis of the most comprehensive data-base of monthly observed precipitation data world-wide built by the GPCC. All observations in this station data base are subject to a multi-stage quality control to minimise the risk of generating temporal inhomogeneities in the gridded data due to varying station densities. This dataset is referred to as VASClimO $\mathrm{v} 1.1^{1}$ and is also freely available for scientific purposes (http://gpcc.dwd.de). Both, CRU TS 2.1 and VASClimO v1.1 data, cover the 50-year period 1951 to 2000 selected in this study for updating the Köppen-Geiger map.

\footnotetext{
${ }^{1}$ Variability Analysis of Surface Climate Observations
} 

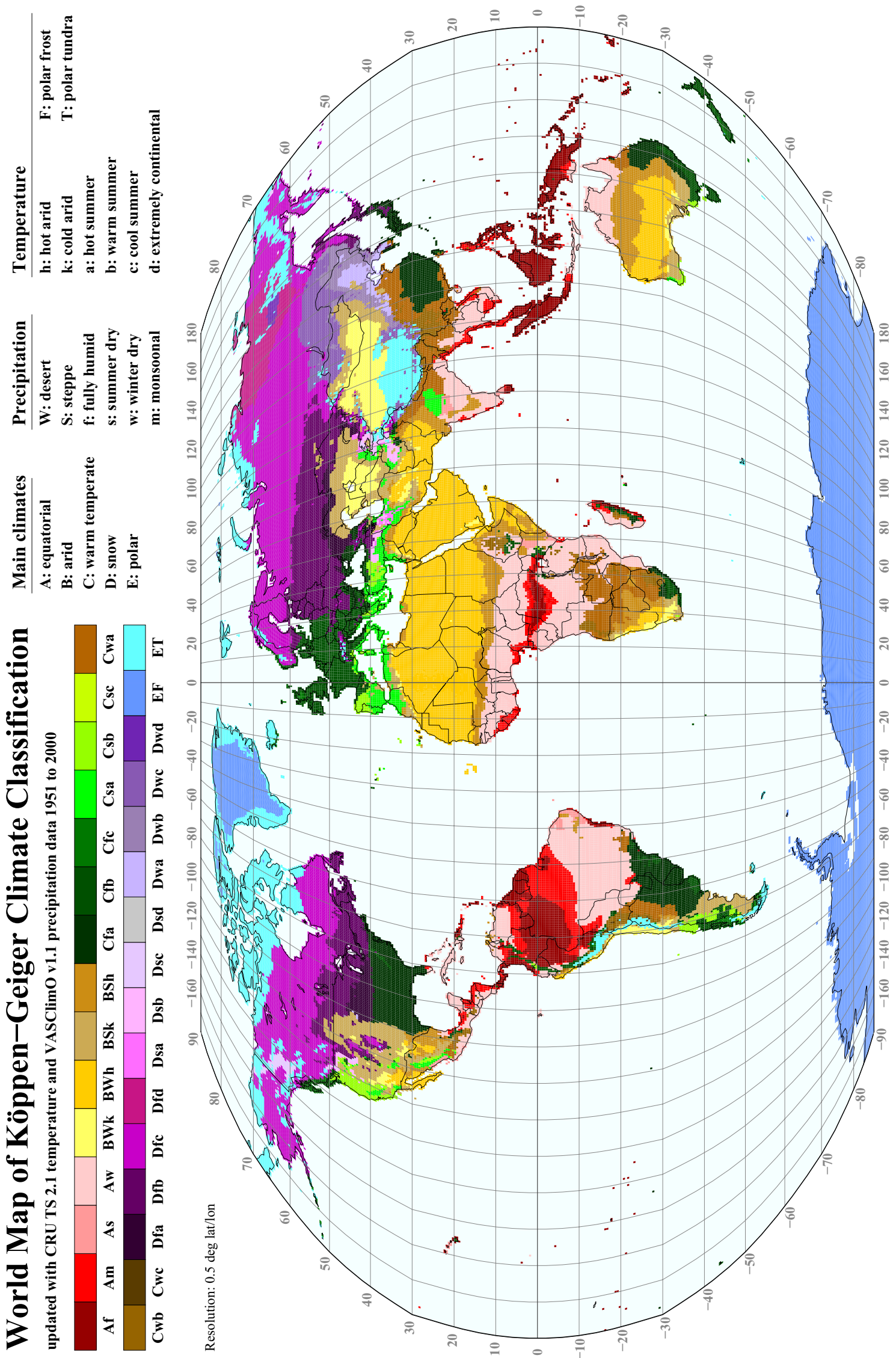

Figure 1: World Map of Köppen-Geiger climate classification updated with mean monthly CRU TS 2.1 temperature and VASClimO v1.1 precipitation data for the period 1951 to 2000 on a regular 0.5 degree latitude/longitude grid. 
Table 2: Key to calculate the third letter temperature classification (h) and (k) for the arid climates (B) and (a) to (d) for the warm temperate and snow climates (C) and (D). Note that for type (b), warm summer, a threshold temperature value of $+10{ }^{\circ} \mathrm{C}$ has to occur for at least four months. The criteria are explained in the text.

\begin{tabular}{lll}
\hline Type & Description & Criterion \\
\hline $\mathrm{h}$ & Hot steppe / desert & $\mathrm{T}_{\mathrm{ann}} \geq+18{ }^{\circ} \mathrm{C}$ \\
$\mathrm{k}$ & Cold steppe /desert & $\mathrm{T}_{\mathrm{ann}}<+18{ }^{\circ} \mathrm{C}$ \\
$\mathrm{a}$ & Hot summer & $\mathrm{T}_{\max } \geq+22^{\circ} \mathrm{C}$ \\
$\mathrm{b}$ & Warm summer & not (a) and at least $4 \mathrm{~T}_{\operatorname{mon}} \geq+10^{\circ} \mathrm{C}$ \\
$\mathrm{c}$ & Cool summer and cold winter & not (b) and $\mathrm{T}_{\min }>-38^{\circ} \mathrm{C}$ \\
$\mathrm{d}$ & extremely continental & like (c) but $\mathrm{T}_{\min } \leq-38^{\circ} \mathrm{C}$ \\
\hline
\end{tabular}

Since various different, sometimes just slightly modified, versions of Köppen's climate classification have been published, the calculation scheme for the KöppenGeiger classes as applied here will now be briefly described (for more details see, e.g., section 13.4.2 of HANTEL, 1989; KRAUS, 2004). This guarantees the reproducibility of the digital data set presented here. The key to the main climates, characterized by the first two letters of the classification, is described in Tab. 1. The annual mean near-surface $(2 \mathrm{~m})$ temperature is denoted by $\mathrm{T}_{\mathrm{ann}}$ and the monthly mean temperatures of the warmest and coldest months by $\mathrm{T}_{\max }$ and $\mathrm{T}_{\min }$, respectively. $\mathrm{P}_{\mathrm{ann}}$ is the accumulated annual precipitation and $\mathrm{P}_{\min }$ is the precipitation of the driest month. Additionally $\mathrm{P}_{\mathrm{smin}}, \mathrm{P}_{\mathrm{smax}}, \mathrm{P}_{\mathrm{wmin}}$ and $\mathrm{P}_{\mathrm{wmax}}$ are defined as the lowest and highest monthly precipitation values for the summer and winter half-years on the hemisphere considered. All temperatures are given in ${ }^{\circ} \mathrm{C}$, monthly precipitations in $\mathrm{mm} / \mathrm{month}$ and $\mathrm{P}_{\text {ann }}$ in mm/year.

In addition to these temperature and precipitation values a dryness threshold $\mathrm{P}_{\text {th }}$ in $\mathrm{mm}$ is introduced for the arid climates (B), which depends on $\left\{\mathrm{T}_{\mathrm{ann}}\right\}$, the $\mathrm{ab}$ solute measure of the annual mean temperature in ${ }^{\circ} \mathrm{C}$, and on the annual cycle of precipitation:

$$
\mathrm{P}_{\mathrm{th}}= \begin{cases}2\left\{\mathrm{~T}_{\mathrm{ann}}\right\} & \begin{array}{l}
\text { if at least } 2 / 3 \text { of the annual } \\
\text { precipitation occurs in winter, }
\end{array} \\
2\left\{\mathrm{~T}_{\mathrm{ann}}\right\}+28 & \begin{array}{l}
\text { if at least } 2 / 3 \text { of the annual } \\
\text { precipitation occurs in summer } \\
\text { otherwise. }
\end{array}\end{cases}
$$

The scheme how to determine the additional temperature conditions (third letter) for the arid climates (B) as well as for the warm temperate and snow climates (C) and (D), respectively, is given in Tab. 2, where $T_{\text {mon }}$ denotes the mean monthly temperature in ${ }^{\circ} \mathrm{C}$.

\section{Results}

Combining the three letters depicted in Tab. 1 and Tab. 2 leads to at most 34 possible different climate classes.
Three of these classes cannot occur by definition since a warm temperate climate $(C)$ needs a temperature of the coldest month $\mathrm{T}_{\min }$ above $-3{ }^{\circ} \mathrm{C}$ while a third letter climate (d), extremely continental, needs a temperature of the coldest month below $-38{ }^{\circ} \mathrm{C}$. Therefore (Csd), (Cwd) and (Cfd) cannot be realised and 31 climate classes remain. Köppen and Geiger recognised that not all of the remaining types occur in a large areal amount and therefore not all of these types may be of climatological importance.

Fig. 1 shows a world map of the Köppen-Geiger climate classification updated with mean monthly CRU TS 2.1 temperature and VASClimO v1.1 precipitation data for the period 1951 to 2000 on a regular 0.5 degree latitude/longitude grid. All 31 climate classes are illustrated with different colours although one of these classes (Dsd) does never occur in this map and some others (Cfc, Csc, Cwc, Dsa, Dsb and Dsc) occur only in very small areas. Having neither temperature nor precipitation data available for Antarctica this region has been set manually to the polar frost climate (EF) by the use of a $0.5^{\circ}$ land-sea-mask operationally applied at the GPCC. Also for Greenland no precipitation data are available. However, this has no influence on the classification since temperature data strongly suggest that the climate of Greenland is either polar tundra (ET) or polar frost $(\mathrm{EF})$ and is therefore independent of precipitation (Tab. 1).

The resulting world map depicted in Fig. 1 corresponds quite well with the historical hand-drawn maps of the Köppen-Geiger climates, but shows more regional details due to the high spatial resolution of 0.5 degree and provides the opportunity for further investigations by applying the underlying digital data. For example, studies on depicting global climate change have been performed by the authors and will be published soon.

\section{Conclusion}

S ANDERSON (1999) stated in the closing sentence of her review paper on climate classifications: Modern atlases and geography textbooks continue to use the 100-year 
old Köppen classification of climate ..., and she asked: Is it not time for modern atmospheric scientists to develop a "new" classification of world climates? We believe that the climate classification concept developed in the first half of the $20^{\text {th }}$ century by Köppen and Geiger is not likely to be discarded in the next future; in fact, it still appears to meet the needs of today's climate scientists (ESSENWANGER, 2001; KRAUS, 2004). Updated on the basis of recent (HANTEL, 2005) and future high resolution climate data and applied to climate model predictions (e.g. LOHMANN et al., 1993; KLEIDON et al., 2000), the Köppen-Geiger classification might have a good chance to be applicable for another 100 years.

The world map of the Köppen-Geiger climate classification presented here as well as the underlying digital data are publicly available and distributed by the Global Precipitation Climatology Centre (GPCC) at the German Weather Service (http://gpcc.dwd.de) and the University of Veterinary Medicine Vienna (http://koeppengeiger.vu-wien.ac.at).

\section{Acknowledgements}

The German Climate Research Programme (DEKLIM) of the Federal Ministry of Education and Research and the FP6 Integrated project GEOLAND (SIP3-CT-2003502871) funded parts of this work.

\section{References}

Beck, C., J. Grieser, B. Rudolf, 2005: A New Monthly Precipitation Climatology for the Global Land Areas for the Period 1951 to 2000. - Climate status report 2004, 181-190, German Weather Service, Offenbach, Germany. Reprint available at http://gpcc.dwd.de.

Essenwanger, O. M., 2001: Classification of Climates, World Survey of Climatology 1C, General Climatology. Elsevier, Amsterdam, 102 pp.
Geiger, R., 1954: Landolt-Börnstein - Zahlenwerte und Funktionen aus Physik, Chemie, Astronomie, Geophysik und Technik, alte Serie Vol. 3, Ch. Klassifikation der Klimate nach W. Köppen. - Springer, Berlin. 603-607.

—, 1961: Überarbeitete Neuausgabe von Geiger, R.: KöppenGeiger / Klima der Erde. (Wandkarte 1:16 Mill.). - KlettPerthes, Gotha.

HANTEL, M. 1989: Climatology, Series Landolt-Börnstein Numerical Data and Functional Relationships in Science and Technology, New Series Vol. 4C2, Ch. The present global surface climate. - Springer, Berlin, 117-474.

- (Ed.), 2005: Observed Global Climate, Series LandoltBörnstein - Numerical Data and Functional Relationships in Science and Technology, New Series Vol. 6A. - Springer, Berlin.

Kleidon, A., K. Fraedrich, M. Heimann, 2000: - A green planet versus a desert world: Estimating the maximum effect of vegetation on the land surface climate. - Climate Change 44, 471-493.

KÖPPEN, W., 1900: - Versuch einer Klassifikation der Klimate, vorzugsweise nach ihren Beziehungen zur Pflanzenwelt. - Geogr. Zeitschr. 6, 593-611, 657-679.

KraUs, H., 2004: Die Atmosphäre der Erde. Eine Einführung in die Meteorologie. - Springer, Berlin, $422 \mathrm{pp}$.

Lohmann, U., R. SAUSEN, L. BengtSSON, U. Cubasch, J. Perlwitz, E. Roeckner, 1993: The Köppen climate classification as a diagnostic tool for general circulation models. - Climate Res. 3, 177-193.

Mitchell, T. D., P. D. Jones, 2005: An improved method of constructing a database of monthly climate observations and associated high-resolution grids. - Int. J. Climatol. 25, 693-712.

Peel, M. C., T. A. McMahon, B. L. Finlayson, F. G. R. WATSON, 2001: Identification and explanation of continental differences in the variability of annual runoff. J. Hydrol. 250, 224-240.

SANDERSON, M., 1999: The classification of climates from Pythagoras to Koeppen. - Bull. Amer. Meteor. Soc. 80, 669-673. 